\title{
Carcass characteristics of purebred and crossbred Nellore females fed solely pasture
}

\author{
Características da carcaça de fêmeas Nelore e cruzadas \\ contemporâneas produzidas exclusivamente em pastagem
}

\author{
Thiago Martins Pivaro ${ }^{1 *}$; Wignez Henrique ${ }^{2}$; Emanuel Almeida de Oliveira ${ }^{3}$; \\ José Luiz Viana Coutinho Filho ${ }^{2}$; Roberto Molinari Peres ${ }^{2}$; Victor Galli Carvalho ${ }^{4}$
}

\begin{abstract}
This research aimed to compare carcasses of purebred and crossbred Nellore females reared uniquely on pasture (Brachiaria decumbens and Brachiaria brizantha cv. Marandu). Breeds assessed consisted of purebred Nellore (16) and Nellore x Santa Gertrudis crossbred (16), being $32 \pm 1.5$ months old. All animals were slaughtered as they reached $450 \mathrm{~kg}$. Crossbred females showed higher slaughter, hot and cold carcass weights and longer lengths $(\mathrm{P}<0.05)$. Conversely, purebred animals attained greater carcass yields $(\mathrm{P}<0.05)$. Nonetheless, crossbred females had higher primal cut weights and plate/ flank percentage $(\mathrm{P}<0.05)$. Also, non-carcass components as kidneys, liver, kidney-pelvic-heart fat showed higher weights for crossbred females $(\mathrm{P}<0.05)$. Thus, regarding beef cattle reared and finished exclusively on grazing areas, crossbred females (Nellore x Santa Gertrudis) may be the most profitable ones for cattle raisers, since they produce heavier slaughtering carcasses. Notwithstanding, they might be interesting for meat industry, for yielding more in prime cuts than purebreds, even if raised at the same conditions and slaughtered at same age.
\end{abstract}

Key words: Bovines. Brachiaria. Commercial cuts. Breeds. Slaughter.

\section{Resumo}

Objetivou-se comparar as características da carcaça de fêmeas bovinas contemporâneas de diferentes grupos genéticos criadas e terminadas exclusivamente em pastagem (Brachiaria decumbens e Brachiaria brizantha cv. Marandu). Foram utilizadas 16 da raça Nelore e 16 Nelore x Santa Gertrudis, com idade média de $32 \pm 1,5$ meses. Os animais foram abatidos no mesmo dia quando as fêmeas Nelore atingiram o peso aproximado de $450 \mathrm{~kg}$. As fêmeas cruzadas apresentaram maiores $(\mathrm{P}<0,05)$ peso de abate, de carcaça quente e resfriada e comprimento da carcaça, já as Nelore apresentaram o melhor rendimento de carcaça $(\mathrm{P}<0,05)$. Os pesos de todos os cortes primários, o rendimento da ponta de agulha e os pesos dos rins, fígado, gordura perirenal-pélvica-inguinal foram maiores $(\mathrm{P}<0,05)$ para as fêmeas cruzadas. Quando se utiliza sistemas de produção de bovinos criados e terminados em pastagem, o uso de fêmeas cruzadas Nelore x Santa Gertrudis é mais vantajoso para o produtor, pois apresentam carcaças mais pesadas, e para a indústria de carne, pelo maior rendimento de cortes nobres, do que fêmeas Nelore criadas nas mesmas condições e abatidas com a mesma idade.

Palavras-chave: Abate. Bovinos. Braquiária. Cortes comerciais. Grupos genéticos.

\footnotetext{
${ }^{1}$ Supervisor Técnico, Potensal Nutrição e Saúde Animal Ltda., Cuiabá, MT, Brasil. E-mail: thiagopivaro@hotmail.com

2 Pesquisadores Científico, APTA, São José do Rio Preto, SP, Brasil. E-mail: wignez@apta.sp.gov.br; lvfilho@gmail.com; peresrm28@gmail.com

${ }^{3}$ Pós-Doutorando, Faculdade de Ciências Agrárias e Veterinárias, UNESP, Jaboticabal, SP, Brasil. E-mail: moroto.oliveira@ hotmail.com

${ }^{4}$ Analista de Qualidade Senior, MCassab Ind. Com. Alimentos Ltda., Rifaina, SP, Brasil. E-mail: victor.galli@hotmail.com

* Author for correspondence 


\section{Introduction}

Female bovines have such a great importance in Brazilian meat industry that, in 2013, among 34.41 million slaughtered animals, $42 \%$ were females. That year, the number of cattle heads slaughtered was near 3.29 million above the previous one, remaining a stable proportion between males and females (IBGE, 2014). Nonetheless, as cattle raising in Brazil is exploited at distinct production systems, females are no longer standardized by age, carcass weight and primal and commercial cut yields, being often below quality standards required by domestic and international markets.

Animal body growth is one of the major characteristics in a meat production system. Uncastrated animals show an improved development than castrated ones, also presenting a higher efficiency to convert diet nutrients into weight gain (LUCHIARI FILHO, 2000). Interestingly, female bovines are different regarding weight gain composition and distribution throughout tissues, since heifers reach maturity earlier than calves, showing less carcass weight and more fat deposition (BERG; BUTTERFIELD, 1976). In view with that, Miller (2001) claimed that female cattle are a good choice to produce well-finished and standardized carcasses.

Crossbreeding zebu and European breeds has promoted benefits to the domestic livestock farming because of hybrid vigor and both breeds complementarity, increasing herd productivity and promoting increased carcass yields, rearing animals faster and more efficiently, with good muscle coverage and high-quality carcasses (JAEGER et al., 2004).

According to Teixeira and Albuquerque (2005), total production rates would increase by $20 \%$ if the environment were favorable, especially for crossbreeds of Bos taurus taurus; which under unfavorable conditions, gains would achieve up to $50 \%$ when crossed with Bos taurus indicus. Since the late $90 \mathrm{~s}$, Brazilian farmers have been embracing such a tool to produce animals that are more efficient and to meet market demands (JUNQUEIRA et al., 1998).

Therefore, this research aimed at assessing quantitative and qualitative carcass characteristics in purebred Nellore and crossbred Nellore x Santa Gertrudis cows reared exclusively on brachiaria pastures (Brachiaria decumbens and Brachiaria brizantha cv. Marandu), once these grass species cover more than $80 \%$ of Brazilian grazing areas (SANTOS et al., 2013).

\section{Material and Methods}

This study was performed at the Unit of Research and Development of the São Paulo State Agency for Agribusiness, Secretariat of Agriculture and Livestock of São Paulo State, in São José do Rio Preto - SP, Brazil.

Thirty-two female bovines of around $32 \pm 1.5$ months of age, being 16 purebred Nellore and 16 crossbred Nellore and Santa Gertrudis. All heifers were daughters of sires belonging to the Animal Breeding Program developed at the Animal Science Institute of Sertãozinho (SP). These breeding bulls had a similar genetic value, in ten random crosses. All animals were reared together in the Unit, fed exclusively on brachiaria pastures (Brachiaria decumbens and Brachiaria brizantha cv. Marandu) during the entire lifetime, but being supplemented with mineral salt (60 g phosphorus/ $\mathrm{kg}$ ).

The animals were monthly weighed without undergoing previous fasting. By reaching $450 \mathrm{~kg}$, these animals were submitted to fasting of solid food and water for 16 hours. Hence then, they were newly weighed and slaughtered the next day in a commercial slaughterhouse, following standards set by the Service of Animal Product Inspection of São Paulo State (SISP). After slaughter, carcass and viscera were separated, weighing liver, kidneypelvic-heart fat and kidneys, individually. Hot carcass was evaluated for weight, total length 
(maximum distance between cranial edge of the first rib, in the center of front edge of isquiopubic symphysis) and inner depth (distance from the front edge of the outer cartilage to the lower edge of the spinal canal between the fifth and sixth dorsal vertebra).

After 24 hours chilling period, carcasses were again weighted and $\mathrm{pH}$ measure taken at between the $12^{\text {th }}$ and the $13^{\text {th }}$ ribs, in the longissimus muscle (LM). Then, carcasses were broken down into forequarter, plate/ flank and hindquarter, and weighted. In each left half carcass, individual muscle samples (LM), between the $11^{\text {th }}$ and the $13^{\text {th }}$ ribs, were collected with bones. These pieces were frozen and then had their loin-eye area measured. This part was removed from a section between the $12^{\text {th }}$ and the $13^{\text {th }}$ rib and, by using a tracing paper, the piece was outlined and its area calculated through AutoCAD (Computer Aided Design. Autodesk, Inc., 2009). In addition, we measured the thickness of subcutaneous fat in Longissimus from the spine final third throughout the entire muscle, using a digital caliper.

Forequarter and hindquarter were deboned and cut into subprimal pieces (commercial cuts), following the slaughterhouse procedures. Forequarter was broken down into foreshank, hump, chuck cuts (chuck cover + neck) and plate/ flank. Yet hindquarter was divided into ribeye, tenderloin, sirloin (rump + rump tail), rump cap, and round cuts such as round topside, round outside, eye round, knuckle, hindshank (heel) and thick flank. Beef trimmings, fat flaps and bones were also removed from primal cuts.

After weighting primal and subprimal cuts, yields were evaluated based on cold right carcass weight. Moreover, primal cuts were also quantified by adding the weights of ribeye, tenderloin, rump, rump tail and rump cap; as well as total cuts by summing round cuts, forequarter and lean trimmings.

The variation in results was tested for its normal distribution by the Cramer-von Mises test (SAS version 9.2) at 5\% probability, making transformations when indicated. For this evaluation, we considered a completely randomized design with two genetic groups, sixteen repetitions and slaughter weight as a covariate variable, being analyzed by SAS statistical software (version 9.2) at $5 \%$ significantly.

\section{Results and Discussion}

The analysis in Table 1 shows that crossbred females had higher weights for live, hot and cold carcass, kidneys, liver and kidney-pelvic-heart fat, besides longer carcasses $(\mathrm{P}<0.05)$. Therefore, it became clear that crossing Nellore and Santa Gertrudis might be an advantageous alternative to increase animal and carcass weights at slaughter, if compared to purebreds. To this day, Brazilian beef prices are still influenced by live and carcass weights and unfortunately quality aspects have been regularly circumvented in trading (JUNQUEIRA et al., 1998), except for particular slaughterhouses.

On the other side, purebreds had improved carcass yields $(\mathrm{P}<0.05)$ (Table 1$)$. This might have occurred due to increasing weights of non-carcass components (kidneys, liver and kidney-pelvic-heart fat) of crossbreds, decreasing carcass yield thereof (JORGE et al., 1999). In line with this, Vaz and Restle (2001) also connected higher carcass yields in purebred zebus with lower weights of paws, head, leather and mainly digestive tract components, whether compared to European half-breeds.

As above-mentioned, final and hot carcass weights prevails in beef cattle trading, so that heavier animals and carcasses make the difference in this market niche. On the wrong hand, ranchers think carcass yields should be taken into consideration as the higher the value, the lower would be losses raised by non-carcass components. So much so, Restle et al. (2005) stated that even though noncarcass components are unpaid, they have become an important source of revenue for slaughterhouses in both domestic and foreign markets. 
Table 1. Carcass characteristics of purebred and crossbred Nellore female bovines reared exclusively on pasture.

\begin{tabular}{|c|c|c|c|c|}
\hline \multirow[b]{2}{*}{ Variable $^{1}$} & \multicolumn{2}{|c|}{ Breed } & \multirow[b]{2}{*}{$\mathbf{P}^{2}$} & \multirow[b]{2}{*}{ MSE $^{3}$} \\
\hline & Nellore & $\begin{array}{c}\text { Nellore } \mathrm{x} \\
\text { Santa Gertrudis }\end{array}$ & & \\
\hline Live weight (kg) & 431.31 & 505.19 & $<0.0001$ & 8.952 \\
\hline Hot carcass weight (kg) & 242.50 & 265.60 & 0.0011 & 3.775 \\
\hline Carcass yield (\%) & 56.25 & 52.60 & $<0.0001$ & 0.445 \\
\hline Cold carcass weight (kg) & 239.89 & 262.55 & 0.0012 & 3.722 \\
\hline Cooling losses $(\%)$ & 1.06 & 1.15 & 0.5003 & 0.060 \\
\hline $\mathrm{pH}(\mathrm{LM})$ & 5.66 & 5.73 & 0.2231 & 0.294 \\
\hline Liver (kg) & 3.87 & 4.28 & 0.0014 & 0.067 \\
\hline Kidneys (kg) & 0.60 & 0.76 & $<0.0001$ & 0.020 \\
\hline KPH (kg) & 11.62 & 19.92 & $<0.0001$ & 0.932 \\
\hline Carcass length (cm) & 130 & 134 & 0.0095 & 0.796 \\
\hline Carcass width $(\mathrm{cm})$ & 37.40 & 38.40 & 0.1378 & 0.335 \\
\hline $\operatorname{REA}\left(\mathrm{cm}^{2}\right)$ & 61.63 & 70.44 & 0.0025 & 1.534 \\
\hline REA ( $\mathrm{cm}^{2} / 100 \mathrm{~kg}$ carcass $)$ & 25.70 & 26.81 & 0.1919 & 0.422 \\
\hline FT & 7.80 & 10.60 & 0.0485 & 0.745 \\
\hline
\end{tabular}

${ }^{1} \mathrm{KPH}$ - Kidney-pelvic-heart fat; FT - Covering fat thickness; REA - Ribeye area ${ }^{2} \mathrm{P}$ - Probability; ${ }^{3} \mathrm{MSE}$ - Mean standard error.

Multiple tissues are deposited at different rates for each animal genetic composition (OWENS et al., 1993), as well as nutritional and reproduction aspects. All females were in similar age and reared under the same conditions; therefore, ribeye area and fat thickness differences between the groups (Table 1) might have arisen from genetics. Crossbred females had higher precocity $(\mathrm{P}<0.05)$, once Santa Gertrudis is 5/8 Shorthorn, besides an improved growth trait, as function of heterosis, and depositing higher amounts of muscle tissue and fat cover. Vaz and Restle (2001) when crossing Charolais and Nellore observed the same effects. Furthermore, according to Berg and Butterfield (1976), British breeds fed high amount of forage are early able to deposit fat into the carcass. Covering fat thickness for both genetic groups were above the requirements (3-6 mm), and all carcasses could be classified as uniform finish. Ribeiro et al. (2001) stated that fat thickness suitable values positively influence carcass protection against dryness during cooling; thus, neither of the genotypes under study have influence cooling losses $(\mathrm{P}>0.05)$.

Table 2 shows that all primal cuts were heavier for crossbred females than purebred ones $(\mathrm{P}<0.05)$, which is related to the highest slaughter and carcass weights reached by these animals. Oliveira et al. (2009) and Goes et al. (2012) ascertained that outstanding weights for primal cuts only occur when slaughter weights are not equal, as observed here.

Yielding of primal cuts showed differences only for plate/ flank cuts, highlighting crossbred females with the highest values $(\mathrm{P}<0.05)$ as seen in Table 2. The literature studies demonstrate that animals arising from Bos taurus taurus genetic basis, commonly achieve higher primal cut yields as for hindquarter and plate/ flank cuts, if compared to a Bos taurus indicus composition (MAY et al., 1992). For instance, Vaz and Restle (2001) reported increased yield for hindquarter cuts of purebred calves in contrast to higher values for plate/ flank cuts of crossbred lines. In addition, Prado et al. (2001) found greater proportions for plate/ flank cuts of crossbred animals (Limousin $\mathrm{x}$ Nellore and Canchim x Nellore). It should be noted that yields of primal and subprimal cuts must be the highest possible for slaughterhouses, since they are directly related to deboning efficiency, and thus for slaughterhouse economy. Conversely, the primal cuts are still used as payment basis to cattle raisers. 
Table 2. Weights and yields of primal cuts from carcasses of purebred and crossbred Nellore female bovines reared exclusively on pasture.

\begin{tabular}{lcccc}
\hline \multirow{2}{*}{ Variable } & \multicolumn{2}{c}{ Breed } & $\mathbf{P}^{\mathbf{1}}$ & MSE $^{2}$ \\
\cline { 2 - 3 } & Nellore & $\begin{array}{c}\text { Nellore } \mathbf{x} \text { Santa } \\
\text { Gertrudis }\end{array}$ & & \\
\hline Weight (kg) & 117.32 & 126.91 & 0.0050 & 1.780 \\
Hindquarter & 92.35 & 100.41 & 0.0024 & 1.394 \\
Forequarter & 30.22 & 35.24 & 0.0002 & 0.744 \\
Plate/ flank & & & & \\
Yield (\%) & 48.90 & 48.34 & 0.0696 & 0.156 \\
Hindquarter & 38.52 & 38.24 & 0.3472 & 0.148 \\
Forequarter & 12.57 & 13.42 & 0.0087 & 0.167 \\
Plate/ flank & & &
\end{tabular}

${ }^{1} \mathrm{P}$ - Probability; ${ }^{2} \mathrm{MSE}$ - Mean standard error.

Table 3 displays that purebred Nellore females had higher yields of round topside, round outside and knuckle $(\mathrm{P}<0.05)$, while crossbred ones how higher values for ribeye $(\mathrm{P}<0.05)$. Hindquarter commercial cuts are taken as prime quality ones if compared to forequarter and plate/ flank. Economically, a greater yield of round cuts is desirable, since it is where the cuts of higher commercial values are taken from (VITTORI et al., 2006).

The breeds assessed here had influence on the yield of all forequarter meat cuts $(\mathrm{P}<0.05)$ (Table $3)$. It is noteworthy saying that forequarter cuts have lower prices compared to the others concerning meat aspect, which is generally darker and tougher with great fat accumulation, especially at plate/ flank area.

Foreshank and hump yields were higher for purebred females $(\mathrm{P}<0.05)$, which can be immediately linked to a zebu phenotype that has a rhomboid hypertrophy (hump). Berg and Butterfield (1968) pointed out that the rhomboid muscle is also associated with front leg connection to neck and chest. However, according Puga et al. (1999), increasing shoulder proportions is not as desirable, since the shoulder cuts (Triceps brachii) are inferior in relation to the round ones, except for some market niche.

Differently, crossbred females outstood by improved yields of chuck + neck and plate/ flank cuts. It may be derived from the fact that these animals have early deposition of fat into the carcass, which, in general, results in increasing proportions of fatty cuts as in plate/ flank, being recognized as fat deposition site in cattle (CIANZIO et al., 1985).

Fat trimmings were heavier in crossbred animals too $(\mathrm{P}<0.05)$, while lean trimmings and bone proportions had no differences $(\mathrm{P}>0.05)$ when comparing both breeds. Once noting that these fractions refer to muscle, fat and bone tissues withdrawn from carcasses during deboning, increased levels of fat flap can have a negative influence on the yield of commercial cuts. Therefore, it is necessary to cut out the excess of external fat to standardize cuts intended to the consumer market. Such issue is typically seen in animals with great deposits of fat in the carcass, as observed in crossbred females here. 
Table 3. Commercial cut yields (\%) for carcasses of purebred and crossbred Nellore female bovines reared exclusively on pasture.

\begin{tabular}{|c|c|c|c|c|}
\hline \multirow[b]{2}{*}{ Variable } & \multicolumn{2}{|c|}{ Breed } & \multirow[b]{2}{*}{$\mathbf{P}^{1}$} & \multirow[b]{2}{*}{$\mathbf{M S E}^{2}$} \\
\hline & Nellore & $\begin{array}{c}\text { Nellore } x \text { Santa } \\
\text { Gertrudis }\end{array}$ & & \\
\hline \multicolumn{5}{|c|}{ Hindquarter cuts } \\
\hline Rib fingers & 0.24 & 0.23 & 0.3699 & 0.008 \\
\hline Ribeye & 6.14 & 6.59 & 0.0006 & 0.070 \\
\hline Tenderloin & 1.62 & 1.59 & 0.5032 & 0.020 \\
\hline Rump & 2.94 & 2.92 & 0.6869 & 0.030 \\
\hline Rump tail & 1.11 & 1.08 & 0.3176 & 0.160 \\
\hline Rump cap & 1.56 & 1.64 & 0.1427 & 0.027 \\
\hline Round topside & 7.53 & 6.98 & $<0.0001$ & 0.068 \\
\hline Round outside & 3.90 & 3.67 & 0.0053 & 0.044 \\
\hline Eye round & 1.92 & 1.92 & 0.9539 & 0.016 \\
\hline Knuckle & 3.92 & 3.62 & 0.0003 & 0.040 \\
\hline Hindshank & 2.96 & 2.90 & 0.3531 & 0.034 \\
\hline Thick flank & 1.42 & 1.39 & 0.7757 & 0.042 \\
\hline \multicolumn{5}{|c|}{ Forequarter cuts } \\
\hline Foreshank & 11.58 & 11.06 & 0.0013 & 0.086 \\
\hline Hump & 2.04 & 0.78 & $<0.0001$ & 0.168 \\
\hline Chuck + Neck & 11.24 & 11.77 & 0.0082 & 0.104 \\
\hline Plate/ flank & 4.58 & 5.14 & 0.0011 & 0.092 \\
\hline \multicolumn{5}{|c|}{ Trimmings and bones } \\
\hline Lean trimmings & 2.07 & 2.15 & 0.3919 & 0.047 \\
\hline Fat flaps & 4.70 & 5.48 & 0.0001 & 0.111 \\
\hline Bones & 15.85 & 15.59 & 0.4930 & 0.186 \\
\hline \multicolumn{5}{|c|}{ Meat cuts } \\
\hline Prime quality cuts ${ }^{2}$ & 13.38 & 13.82 & 0.0198 & 0.096 \\
\hline Total $^{3}$ & 66.79 & 65.44 & 0.0001 & 0.190 \\
\hline
\end{tabular}

${ }^{1} \mathrm{P}-$ Probability; ${ }^{2} \mathrm{MSE}-$ Mean standard error; ${ }^{2}$ Prime quality cuts $=$ ribeye + tenderloin + rump + rump tail + rump cap; ${ }^{3}$ Total $=$ hindquarter cuts + forequarter cuts + lean trimmings.

When combining the earnings of forequarter and hindquarter cuts, Nellore females stood out the most (Table 3); however, separately, crossbred ones were most efficient regarding hindquarter cuts $(\mathrm{P}<0.05)$.

In recent years, livestock farmers have been systematically slaughtering females in Brazil and, finishing phase of these animals is important. As shown in this study, it may reach satisfactory carcass weights, levelling prices currently paid by males, which would enable higher working capital for such farming activity, primarily because of female precocity. If it is possible to carry out crossings, animal performance and precocity will further contribute to the results.

\section{Conclusion}

When rearing and finishing bovines exclusively on pasture, crossbred females Nellore x Santa Gertrudis may be more advantageous to the livestock farmers, since these animals have heavier carcasses, as well as for the meat industry because of the higher yields of primal cuts compared to purebred Nellore females, being reared under the same conditions and slaughtered at the same age. 


\section{Acknowledgements}

We want to thank the Foundation for Research Support of São Paulo State (Fundação de Amparo à Pesquisa do Estado de São Paulo - FAPESP) by financial support provided to this research (Process $\left.n^{\circ} 2014 / 20603-4\right)$.

\section{References}

AUTODESK, Inc, Auto Computer Aided Design, Release 18.0: Autodesk, Inc., 2009. Conjunto de programas. 1 CD-ROM.

BERG, R. T.; BUTTERFIELD, R. M. Growth patterns of bovine muscle, fat and bone. Journal of Animal Science, Champaign, v. 27, n. 3, p. 611-619, 1968.

BERG, R. T.; BUTTERFIELD, R. M. New concepts of cattle growth. Sydney: Sydney University Press, 1976. 240 p.

CIANZIO, D. S.; TOPEL, D. G.; WHITEHURST, G. B.; BEITZ, D. C.; SELF, H. L. Adipose tissue growth and gellularity: changes in bovine adipocyte size and number. Journal of Animal Science, Champaign, v. 60, n. 4, p. 970-976, 1985.

GOES, R. H. T. B.; CERILO, S. L. N.; LIMA, H. L.; FERNANDES, A. R. M.; OLIVEIRA, E. R.; SOUZA, K. A.; PATUSSI, R. A.; BRABES, K. C. S.; GRESSLER, M. G. M. Torta de girassol em substituição ao farelo de soja nos suplementos de novilhas: desempenho e características de carcaça. Revista Brasileira de Saúde Produção Animal, Salvador, v. 13, n. 2, p. 396-409, 2012.

INSTITUTO BRASILEIRO DE GEOGRAFIA E ESTATÍSTICAS - IBGE. Estatísticas da produção pecuária. Brasília: IBGE, 2014. Acesso em: <http:// www.ibge.gov.br/.../abate-leite-couro-ovos_201303 publ_completa.pdf>. Acesso em: 20 abr. 2014.

JAEGER, S. M. P. L.; DUTRA, A. R.; PEREIRA, J. C.; OLIVEIRA, I. S. C. Características da carcaça de bovinos de quatro grupos genéticos submetidos a dietas com ou sem adição de gordura protegida. Revista Brasileira de Zootecnia, Viçosa, MG, v. 33, n. 6, p. 1876-1887, 2004. Suplemento 1.

JORGE, A. M.; FONTES, C. A. A.; PAULINO, M. F.; GOMES JUNIOR, P.; FERREIRA, J. N. Desempenho produtivo de animais de quatro raças zebuínas, abatidos em três estádios de maturidade. 2. Características da carcaça. Revista Brasileira de Zootecnia, Viçosa, MG, v. 28, n. 1, p. 381-389, 1999.
JUNQUEIRA, J. O. B.; VELLOSO, L.; FELICIO, P. E. Desempenho, rendimentos de carcaça e cortes de animais, machos e fêmeas, mestiços Marchigiana $\mathrm{x}$ Nelore, terminados em confinamento. Revista Brasileira de Zootecnia, Viçosa, MG, v. 27, n. 6, p. 1199-1205, 1998.

LUCHIARI FILHO, A. Pecuária da carne bovina. São Paulo: A. Luchiari Filho, 2000. 134 p.

MAY, S. G.; MIES, W. E.; EDWARDS, J. W.; WILLIANS, F. L.; WISE, J. W.; MORGAN, J. B.; SAVELL, J. W.; CROSS, H. R. Beef carcass composition of slaughter cattle different in frame size, muscles score, and external fatness. Journal of Animal Science, Champaign, v. 70, n. 8, p. 2431-2445, 1992.

MILLER, R. K. Perspectivas da bovinocultura de corte no Brasil. In: CONGRESSO BRASILEIRO DE CIÊNCIA E TECMOLOGIA DE CARNES, 2001, Campinas. Anais... Campinas: CTC/ITAL, 2001. p. 123-142.

OLIVEIRA, E. A.; SAMPAIO, A. A. M.; FERNANDES, A. R. M.; HENRIQUE, W.; OLIVEIRA, R. V.; RIBEIRO, G. M. Desempenho e características de carcaça de tourinhos Nelore e Canchim terminados em confinamento recebendo dietas com cana-de-açúcar e dois níveis de concentrado. Revista Brasileira de Zootecnia, Viçosa, MG, v. 38, n. 12, p. 2465-2472, 2009.

OWENS, F. N.; DUBESKI, P.; HANSON, C. F. Factors that alter the growth and development of ruminants. Journal of Animal Science, Champaign, v. 71, n. 11, p. 3138-3150, 1993.

PRADO, C. S.; PADUA, J. T.; CORREA, M. P. C; SAINZ, R. D.; MAGNABOSCO, C. U.; RESENDE, L. $\mathrm{S}$. Avaliação de rendimento e características de carcaça, em bovinos de corte de diferentes grupos genéticos, castrados e inteiros. In: CONGRESSO BRASILEIRO DE TECNOLOGIA DE CARNES, 2001, São Pedro. Anais... Campinas: ITAL, 2001. p. 88-89.

PUGA, D. M. U.; CONTRERAS, C. J. C.; TURNBULL, M. R. Avaliação do amaciamento de carne bovina de dianteiro (Triceps brachii) pelos métodos de maturação, estimulação elétrica, injeção de ácidos e tenderização mecânica. Ciência e Tecnologia de Alimentos, Campinas, v. 19 , n. 1 , p. 88-96, 1999.

RESTLE, J.; MENEZES, L. F. G.; ARBOITTE, M. Z.; PASCOAL, L. L.; PACHECO, P. S.; PADUA, J. T. Características das partes não-integrantes da carcaça de novilhos $5 / 8$ Nelore $3 / 8$ Charolês abatidos em três estádios de desenvolvimento. Revista Brasileira de Zootecnia, Viçosa, MG, v. 34, n. 4, p. 1339-1348, 2005. 
RIBEIRO, T. R.; PEREIRA, J. C.; OLIVEIRA, M.V. M.; QUEIROZ, A. C.; CECON, P. R.; LEÃO, M. I.; ALVARENGA E MELO, R. C. Características de carcaça de bezerros holandeses para produção de vitelos recebendo dietas com diferentes níveis de concentrado. Revista Brasileira de Zootecnia, Viçosa, MG, v. 30, n. 6, p. 2154-2162, 2001. Suplemento.

SANTOS, M. E. R.; FONSECA, D. M.; GOMES, V. M. Forage accumulation in brachiaria grass under continuous grazing with single or variable height during the seasons of the year. Revista Brasileira de Zootecnia, Viçosa, MG, v. 42, n. 5, p. 312-318, 2013.

TEIXEIRA, R. A.; ALBUQUERQUE, L. G. Heteroses materna e individual para ganho de peso pré-desmama em bovinos Nelore $\times$ Hereford e Nelore $\times$ Angus. Arquivos Brasileiros de Medicina Veterinária e Zootecnia, Belo Horizonte, v. 57, n. 4, p. 518-523, 2005.
VAZ, F. N.; RESTLE, J. Efeito de Raça e Heterose para características de carcaça de novilhos da primeira geração de cruzamento entre Charolês e Nelore. Revista Brasileira de Zootecnia, Viçosa, MG, v. 30, n. 2, p. 409416, 2001.

VITTORI, A.; QUEIROZ, A. C.; RESENDE, F. D.; JUNIOR, A. G.; ALLEONI, G. F.; RAZOOK, A. G.; FIGUEIREDO, L. A.; GESUALDI, C. L. S. Características de carcaça de bovinos de diferentes grupos genéticos, castrados e não-castrados, em fase de terminação. Revista Brasileira de Zootecnia, Viçosa, MG, v. 35, n. 5, p. 2085-2092, 2006. 